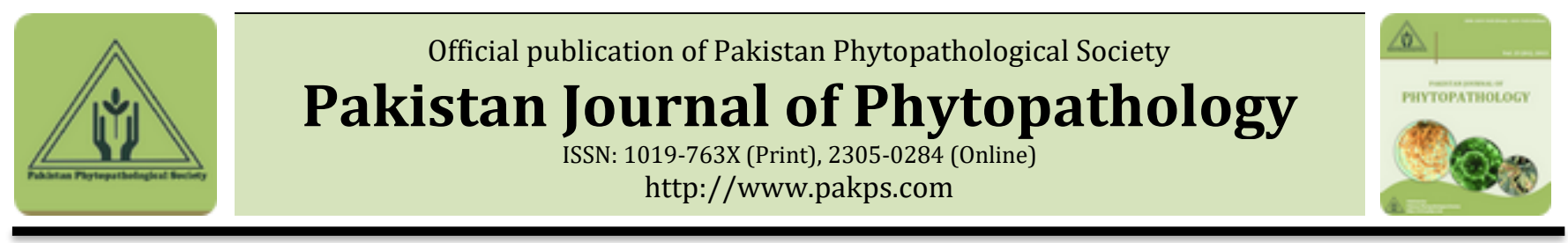

\title{
INDUCTION OF RESISTANCE IN TOMATO PLANTS AGAINST TOMATO LEAF CURL VIRUS BY USING BIOCHAR AND SEED PRIMING
}

\author{
aMuhammad A. Zeshan, aYasir Iftikhar, bSafdar Ali*, cNadeem Ahmed, dMuhammad U. Ghani, \\ eMuhammad Kamran, a Qaiser N. Khan \\ a Department of Plant Pathology, College of Agriculture, University of Sargodha, Sargodha, Pakistan. \\ ${ }^{b}$ Department of Plant Pathology, University of Agriculture, Faisalabad, Pakistan. \\ ${ }^{c}$ Department of Plant Pathology, Muhammad Nawaz Sharif University of Agriculture, Multan, Pakistan. \\ d Institute of Soil and Environmental Sciences, University of Agriculture, Faisalabad, Pakistan. \\ e Department of Agronomy, College of Agriculture, University of Sargodha, Sargodha, Pakistan.
}

\begin{abstract}
A B S T R A C T
The experiment was conducted to check the effects of biochar and different priming agents on whitefly transmitted tomato leaf curl virus. Biochar was applied to potting mixture at $1 \%, 2 \%$ and $3 \%$ concentration. In order to check the effects of priming, tomato seedlings were primed with $\mathrm{NaCl}$, glycerine and distilled water at three concentrations. After biochar application $22.43 \%$ disease severity was recorded that was significantly lower than control (40.12\%). In graft inoculated plants, disease severity was in $15.32 \%$ while in control $50.23 \%$ disease severity was recorded. From primed seedling $\mathrm{NaCl}$ and glycerine shows good results then distilled water. In case of biochar, disease reduction was more at higher concentration (3\%) than other two concentrations. Priming gave better results in case of whitefly inoculation.
\end{abstract}

Keywords: Defence, Resistance, Biochar, Priming, Virus and Tomato.

\section{INTRODUCTION}

Tomato (Solanum lycopersicum L.) belongs to nightshade family and its cultivation started in South American region (Knapp, 2000). Tomato provides balanced and energetic dietary components as it contains various mineral nutrients, vitamins and lycopene (Glick et al., 2009). Apart from second most consumable vegetable, it is used in many industrial products and also has share a considerable share in export (Nagaraju et al., 2002). The quality and quantity of tomato produce is badly affected when it is challenged by different disease causing agents (Mari et al., 2007). Tomato crop is heavily devastated by leaf curl disease caused by tomato leaf curl virus (TLCV) (Polston and Anderson, 1997). This disease is prevalent

Submitted: January 03, 2018

Revised: April 04, 2018

Accepted for Publication: June 01, 2018

* Corresponding Author:

Email: safdar147m@yahoo.com

(C) 2017 Pak. J. Phytopathol. All rights reserved. all over the world (Valverde et al., 2001). Under epidemic conditions it may cause $80-100 \%$ yield losses (Moriones et al., 2017). Tomato leaf curl virus (TLCV) is a DNA virus from the genus Begomovirus and the family Geminiviridae (Gutierrez, 1999). TLCV causes the most destructive disease of tomato, and it can be found in tropical and subtropical regions causing severe economic losses (Moriones and Navas-Castillo, 2000). TLCV virus is transmitted by an insect vector, the whitefly (Bemisia tabaci), commonly known as the silver leaf whitefly or the sweet potato whitefly that comes from family Aleyrodidae and order Hemiptera (Ghanim et al., 1998). The primary host for TLCV is the tomato plant, and other plant hosts where TLCV infection has been found include eggplant, potato, tobacco, beans, and peppers (Anfoka et al., 2009). Diseased plants become stunted with upward and downward foliage curling and show chlorotic symptoms (Papayiannis et al., 2011). Due to the rapid spread of TLCV in the last few decades, there is an increased focus in research trying to understand 
and manage this damaging pathogen (Lapidot and Polston, 2006). Some interesting findings include virus being sexually transmitted from infected males to noninfected females (vice versa), and an evidence that TLCV is transovarially transmitted to offspring for two generations (Melzer et al., 2010). In the past, different management options including management of insect vectors, removal of weed hosts and adjustment in sowing dates were used against tomato leaf curl virus disease (Polston and Lapidot, 2007). This work was conducted to find out the non-conventional ways for the management of tomato leaf curl virus instead of using insecticides and plant extracts against whitefly. Biochar and priming could trigger the plant mechanisms for maintaining the incoming stress and fending off the pathogen. Effect of biochar and different seedling priming agents was evaluated against TLCV disease severity.

\section{MATERIALS AND METHODS}

Field survey and sample collection: Tomato field in the research area Department of Horticulture, University College of Agriculture, University of Sargodha, Sargodha (Pakistan) was surveyed. Tomato leaf curl virus disease was assessed in the aforementioned tomato field $\left(72.740^{\circ} \mathrm{N}\right.$ and Longitude $32.6861^{\circ} \mathrm{E}$ ). Diseased leaves and stems were detached from the symptomatic plants to perform biological assays in the greenhouse. Whitefly was collected from the diseased plants by using aspirator.

Experimental plan and Design: Experiment was conducted under greenhouse conditions using CRD (Completely Randomized Design). The purpose was to evaluate the efficacy of biochar and priming against the tomato leaf curl virus disease. Pots were filled with soil, sand and farm yard manure (FYM) in equal proportions (50:50). Each treatment was replicated three times. Tomato variety Pakit was transplanted in pots. Recommended agronomic practices were followed.

Preparation of priming solutions: Seedlings were primed with sodium chloride $(\mathrm{NaCl})$, glycerine and distilled water before transplanting. For priming with $0.2 \mathrm{M} \mathrm{NaCl}, 5.85 \mathrm{~g}$ of salt was dissolved in 1 liter distilled water. Glycerine solution was prepared by taking $50 \mathrm{ml}$ of $5 \%$ glycerine and dissolving in $1000 \mathrm{ml}$ of distilled water. Seedlings were dipped in the solutions for 1 hour (Tufe, 2016).

Application of Biochar: Twenty pots were reserved for Biochar experiment. Biochar was prepared with the help of maize clipart without grains. This was prepared by heating them in a tin for 2 hours (Yeboah et al., 2016). Biochar was applied in 15 pots by $1-3 \%$ of total mixture in the pot.

Biological assays: Ten pots were used for biological assays, out of which five were transplanted with tomato and five with indicator plants. Suspected viruliferous whiteflies collected from the infected fields were released on to the potted plants covered with polythene sheet. Similarly, leaf patch and cleft grafting techniques were also used for the confirmation of virus. Symptoms were observed on the plants after one week. After the successful completion of biological assays, viruliferous whiteflies were used to inoculate the primed and biochar amended plants.

\section{DATA RECORDING AND STATISTICAL ANALYSIS}

Disease severity data were recorded at weekly intervals as follows. Data was subjected to ANOVA and means were compared by LSD test. Analysis was done through Statix 8.1 software.

$$
\text { Disease serverity (\%) } \frac{\text { No. of diseased leaves }}{\text { Total No. of leaves }} \times 100
$$

(Bhyan et al., 2007).

\section{RESULTS}

Biochar and three priming agents were tested against TLCV disease severity under controlled conditions. All the treatments were used at three concentrations $(1 \%$, $2 \%$ and $3 \%$ ). Significant reduction in disease severity was recorded in tomato plants treated biochar and priming agents (distilled water, $\mathrm{NaCl}$ and Glycerol).

Biochar amendment with potting mixture was the most effective at 3\% followed by 2 and $1 \%$ respectively as compared to control in both graft and whitefly inoculation (Figure 1,2). However, better results were recorded in graft inoculated tomato plants. Mixing of biochar at highest concentration (3\%) showed minimum disease severity.

Primed plants with all three agents retained the TLCV infection and showed significant decrease in disease severity as compared to non-primed tomato plants. Priming with distilled water gave better reduction in whitefly inoculated plants than grafted ones as compared to control (Figure 3). All three concentrations of $\mathrm{NaCl}$ performed better against TLCV disease severity in graft and whitefly inoculated plants when compared with untreated check (Figure 4). 


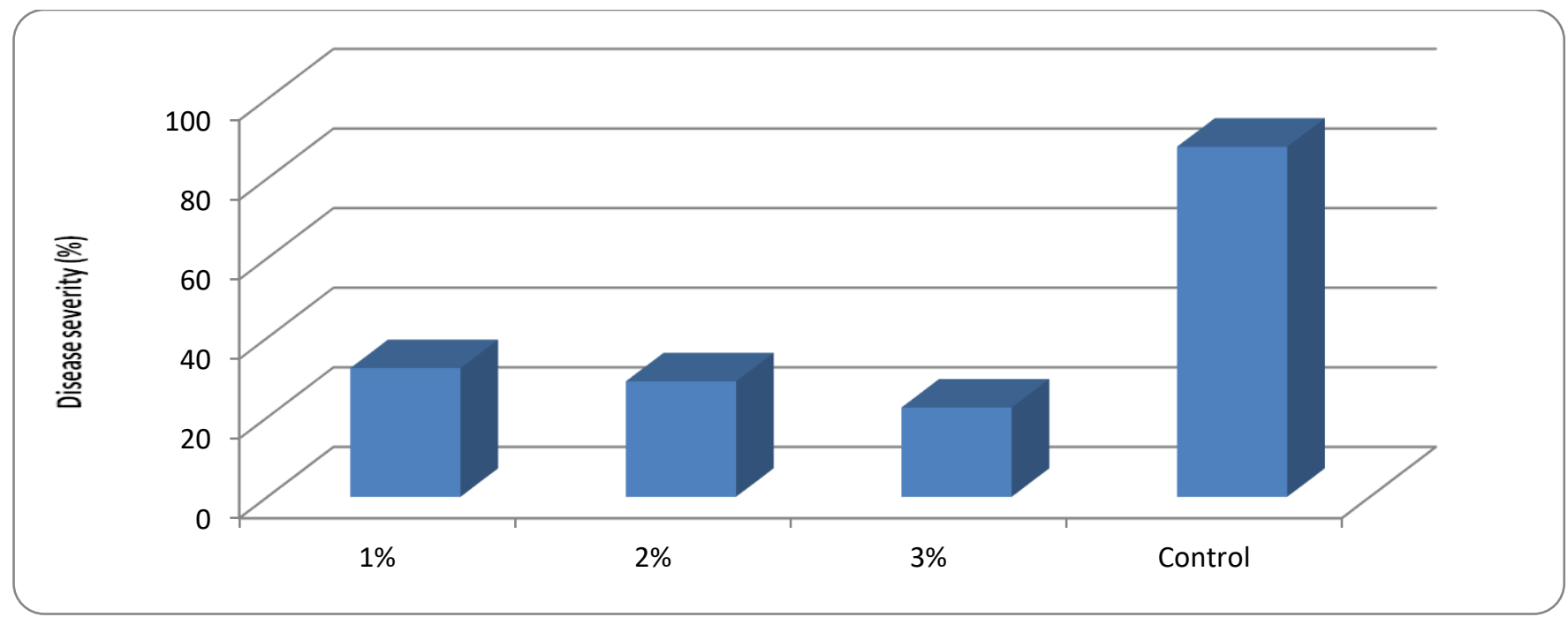

Figure 1. TLCV disease severity in whitefly inoculated tomato plants treated with biochar in potting mixture.

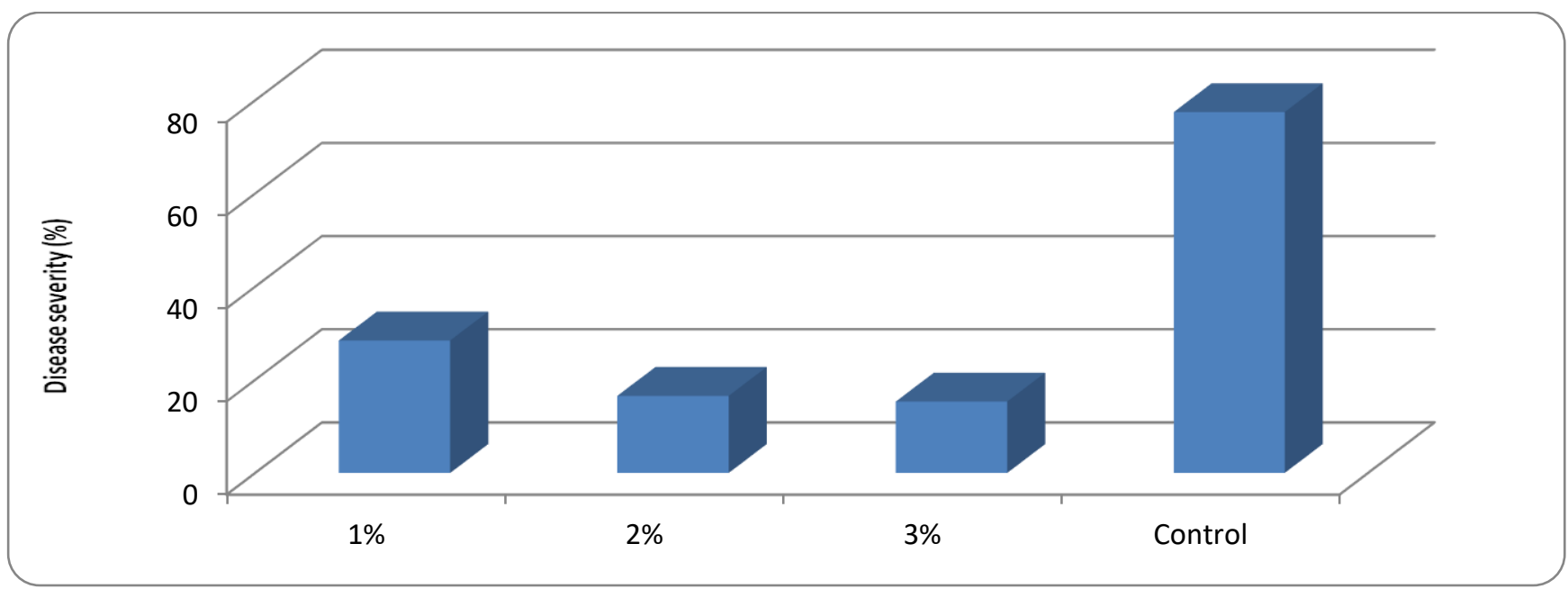

Figure 2. TLCV disease severity in grafted tomato plants treated with biochar in potting mixture.

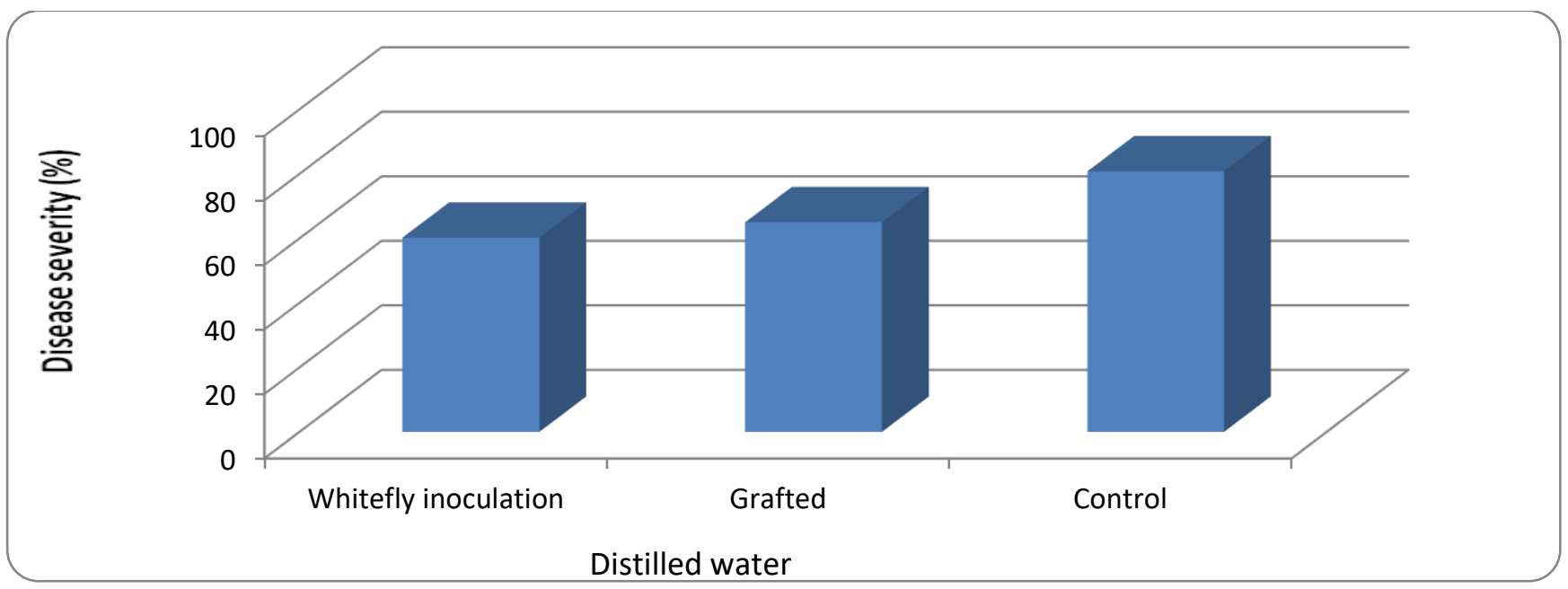

Figure 3. Effect of distilled water priming on TLCV disease severity in whitefly and grafted inoculated plants. 
$\mathrm{NaCl}$ was the most effective in reducing the disease at $3 \%$ concentration while maximum disease was observed in plants primed with $1 \%$ concentration followed by non-primed. The overall disease reduction was higher in whitefly inoculated plants than grafted ones in $\mathrm{NaCl}$ priming.

Among two sets of tomato plants that were stressed with two inoculation methods, glycerol reduced the disease upto 36 and $40 \%$, respectively in whitefly and graft inoculation. Disease severity was the lowest in plants where glycerol was applied in 3\% concentration while it was the highest in $1 \%$ concentration after control.

As a whole high dose of biochar and priming agents were effective in reducing the disease severity. Biochar gave better results in graft inoculated plants whereas all priming agents performed better in whitefly inoculated tomato plants. Among priming agents, minimum disease severity was exhibited by glycerol followed by $\mathrm{NaCl}$ and distilled water.

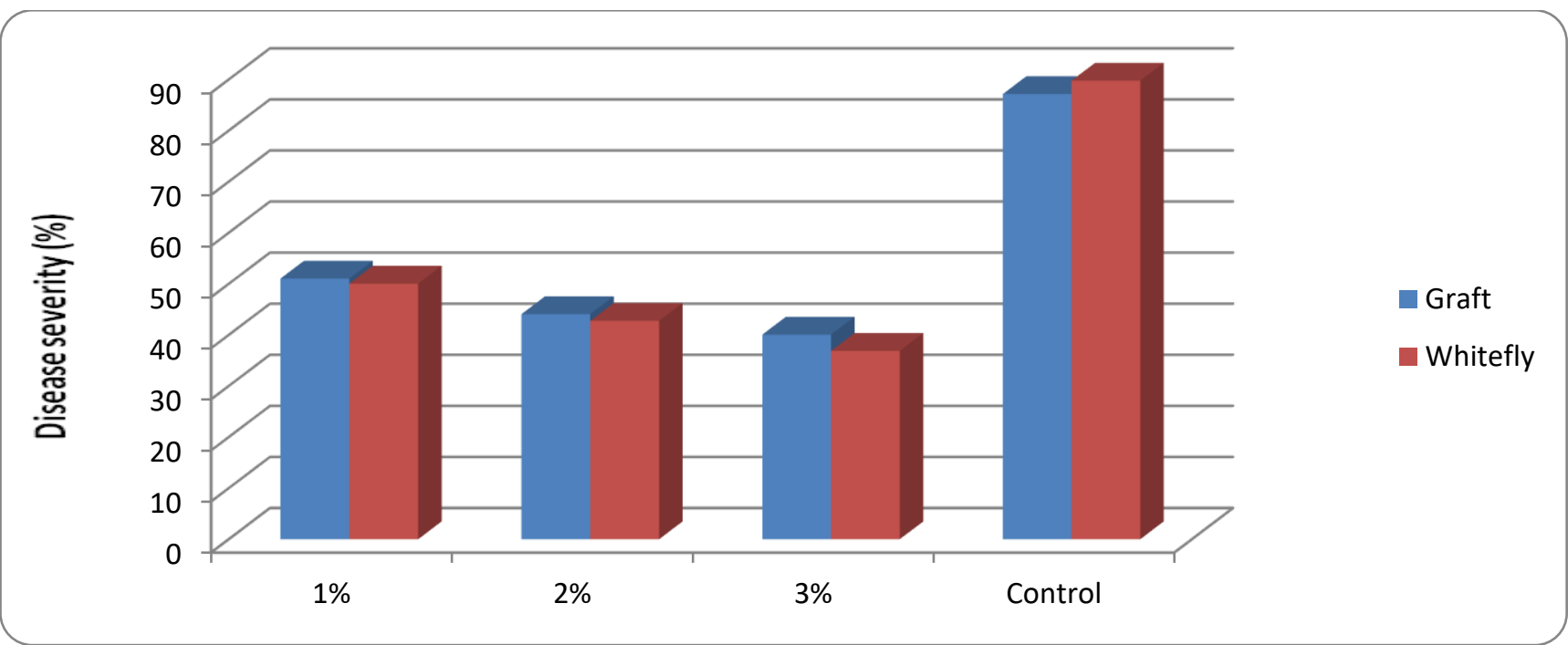

Figure 4. Effect of $\mathrm{NaCl}$ priming on TLCV disease severity in whitefly and grafted inoculated plants.

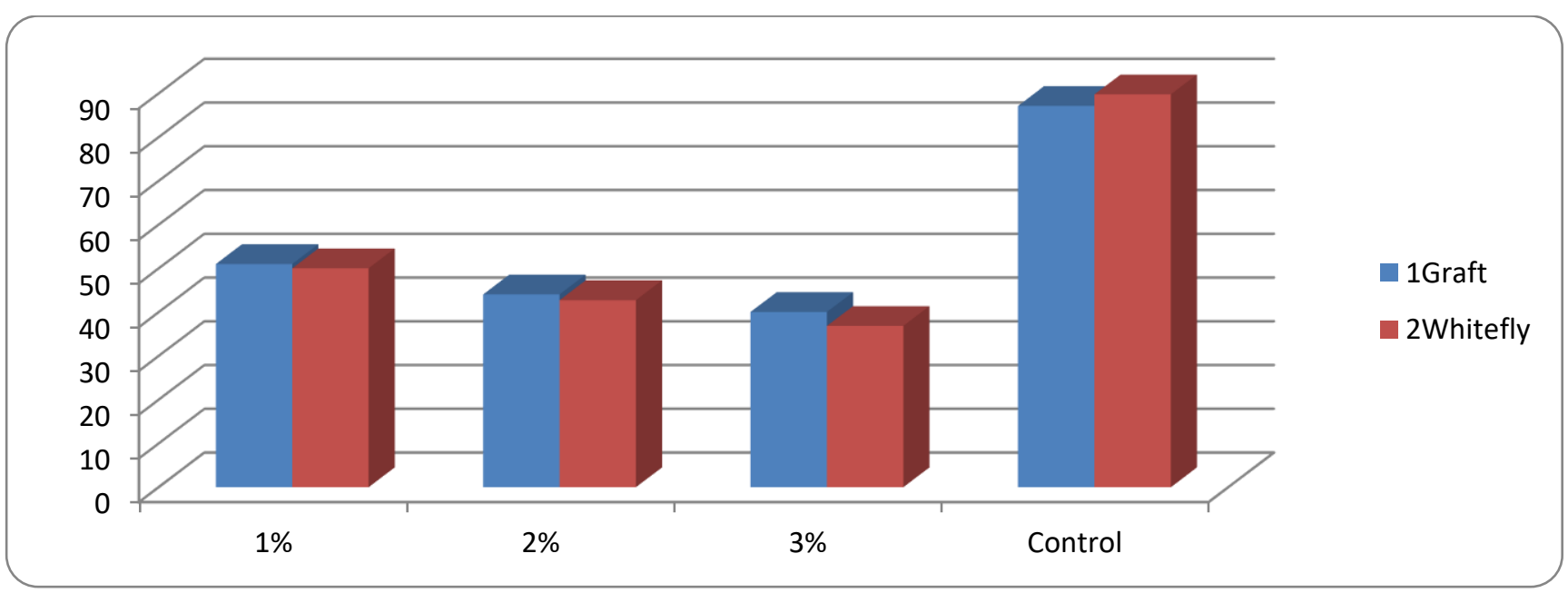

Figure 5. Effect of Glycerine priming on TLCV disease severity in whitefly and grafted inoculated plants.

\section{DISCUSSIONS}

Tomato plants treated with different quantities of biochar significantly reduced the disease severity. The results of this experiment are in close conformity with the results of Elad, (2010) who concluded that biochar could reduce the disease severity upto $68.65 \%$. Application of biochar changes soil physical properties that enhance the systemic acquired resistance in plants 
(Elad et al., 2011). Due to improvement in physical conditions of soil, the disease triangle may be affected (Whitman et al., 2016). Biochar increases nutrients availability to plants (Silber et al., 2010) that affect the plant growth and strengthen the plant biochemical mechanisms (Graber et al., 2013). Nutrients enhance the accumulation of inhibitory substances by altering morphology, histology and functions of the tissues (Datnoff et al., 2007). Calcium affects the plant defense by strengthening cell wall, cell membrane and middle lamella (Bateman and Basham, 1976). Biochar also releases hormone like compounds that are absorbed by the plants and trigger the existing biochemical mechanisms (Graber et al., 2010).

Priming induces the disease resistance in plants at cell level and encounters the incoming stress (Ahn et al., 2007). Seedling or seed treatment with different agents may affect the systemic acquired resistance mechanisms. Defense in treated plants activates quickly upon pathogenic attack (Conrath, 2009). Defense activation speeds up bursting of reactive oxygen species and regulating the genes (Slaughter et al., 2012). Priming increases, the receiving of pathogenic signals and stimulating the plant defense signals (Conrath et al., 2006). Molecular characterization of primed plants revealed the increased mitogen activated protein kinases (Conrath, 2011). Primed plants might develop stability against pathogenic exposure and are ready to fend off the physiological interruption by it (Frost et al., 2008). However, the application of biochar was effective than primed seeds and from primed seeds $\mathrm{NaCl}$ and glycerol showed good results than distilled water. Glycerol increases the production of pathogenesis related proteins and reactive oxygen species in plants (Zhang et al., 2015). Signals that activated the defense were stimulated by glycerol (Mandal et al., 2012). The result of primed seeds showed close conformity with the result of (Ashraf, 2007) whose study concluded that primed seed control $62 \%$ of the disease.

On the basis of aforementioned facts it can be concluded that both biochar and priming might be the best source of defense activation in tomato plants against tomato leaf curl virus. These two strategies would also be helpful in reducing the environmental pollution caused by injudicious use of pesticides.

\section{REFERENCES}

Ahn, I.-P., S.-W. Lee and S.-C. Suh. 2007. Rhizobacteria-
Induced Priming inArabidopsisIs Dependent on Ethylene, Jasmonic Acid, andNPR1. Molecular Plant-Microbe Interactions, 20: 759-768.

Anfoka, G., F. Haj Ahmad, M. Abhary and A. Hussein. 2009. Detection and molecular characterization of viruses associated with tomato yellow leaf curl disease in cucurbit crops in Jordan. Plant Pathology, 58: 754-762.

Ashraf, M. and H. Rauf. 2001. Inducing salt tolerance in maize (Zea mays L.) through seed priming with chloride salts: Growth and ion transport at early growth stages. Acta Physiologiae Plantarum, 23: 407-414.

Bateman, D. F. and H. G. Basham. 1976. Degradation of Plant Cell Walls and Membranes by Microbial Enzymes. Physiological Plant Pathology. Springer Berlin Heidelberg, pp. 316-355.

Bhyan, S. B., M. A. H. Chowdhury, M. M. Alam and M. S. Ali. 2007. Incidence and Severity of Tomato Yellow Leaf Curl Virus under Phytopesticidal Management. International Journal of Agricultural Research, 2: 590-598.

Conrath, U. 2009. Chapter 9 Priming of Induced Plant Defense Responses. Advances in Botanical Research. Elsevier, pp. 361-395.

Conrath, U. 2011. Molecular aspects of defence priming. Trends in Plant Science, 16: 524-531.

Conrath, U., G. J. M. Beckers, V. Flors, P. García-Agustín, G. Jakab, F. Mauch, M.-A. Newman, C. M. J. Pieterse, B. Poinssot, M. J. Pozo, A. Pugin, U. Schaffrath, J. Ton, D. Wendehenne, L. Zimmerli and B. Mauch-Mani. 2006. Priming: Getting Ready for Battle. Molecular Plant-Microbe Interactions, 19: 1062-1071.

Datnoff, L.E., W.H. Elmer and D.M. Huber. 2007. Mineral nutrition and plant disease. American Phytopathological Society. St. Paul.

Elad, Y., E. Cytryn, Y. M. Harel, B. Lew and E. R. Graber. 2011. The biochar effect: plant resistance to biotic stresses. Phytopathologia Mediterranea, 50: 335.

Elad, Y., D. R. David, Y. M. Harel, M. Borenshtein, H. B. Kalifa, A. Silber and E. R. Graber. 2010. Induction of Systemic Resistance in Plants by Biochar, a Soil-Applied Carbon Sequestering Agent. Phytopathology, 100: 913-921.

Frost, C. J., M. C. Mescher, J. E. Carlson and C. M. De Moraes. 2008. Plant Defense Priming against 
Herbivores: Getting Ready for a Different Battle. PLANT PHYSIOLOGY, 146: 818-824.

Ghanim, M., S. Morin, M. Zeidan and H. Czosnek. 1998. Evidence for Transovarial Transmission of Tomato Yellow Leaf Curl Virus by Its Vector, the WhiteflyBemisia tabaci. Virology, 240: 295-303.

Glick, E., Y. Levy and Y. Gafni. 2009. The viral etiology of tomato yellow leaf curl disease - a review. Plant Protection Science, 45: 81-97.

Graber, E. R., Y. Meller Harel, M. Kolton, E. Cytryn, A. Silber, D. Rav David, L. Tsechansky, M. Borenshtein and Y. Elad. 2010. Biochar impact on development and productivity of pepper and tomato grown in fertigated soilless media. Plant and Soil, 337: 481-496.

Graber, E. R., L. Tsechansky, B. Lew and E. Cohen. 2013. Reducing capacity of water extracts of biochars and their solubilization of soil $\mathrm{Mn}$ and Fe. European Journal of Soil Science, 65: 162-172.

Gutierrez, C. 1999. Geminivirus DNA replication. Cellular and Molecular Life Sciences (CMLS), 56: 313-329.

Knapp, S. 2002. Solanum section Geminata (G. Don) Walp. Solanaceae) Fl. Neotrop, 84: 1-405.

Lapidot, M. a. J. E. P. 2006. Natural Resistance Mechanisms of Plants to Viruses. Springer Netherlands.

Mandal, M. K., A. C. Chandra-Shekara, R.-D. Jeong, K. Yu, S. Zhu, B. Chanda, D. Navarre, A. Kachroo and P. Kachroo. 2012. Oleic Acid-Dependent Modulation of Nitric Oxide Associated1 Protein Levels Regulates Nitric Oxide-Mediated Defense Signaling inArabidopsis. The Plant Cell, 24: 16541674.

Mari, F., R. Memon and H. Lohano. 2007. Measuring returns to scale for onion, tomato and chillies production in Sindh province of Pakistan. International Journal of Agriculture and Biology (Pakistan).

Melzer, M. J., D. Y. Ogata, S. K. Fukuda, R. Shimabuku, W. B. Borth, D. M. Sether and J. S. Hu. 2010. First Report of Tomato yellow leaf curl virus in Hawaii. Plant Disease, 94: 641-641.

Moriones, E. and J. Navas-Castillo. 2000. Tomato yellow leaf curl virus, an emerging virus complex causing epidemics worldwide. Virus Research, 71: 123-134.

Moriones, E., S. Praveen and S. Chakraborty. 2017.
Tomato Leaf Curl New Delhi Virus: An Emerging Virus Complex Threatening Vegetable and Fiber Crops. Viruses, 9: 264.

Nagaraju, N., H. M. Venkatesh, H. Warburton, V. Muniyappa, T. C. B. Chancellor and J. Colvin. 2002. Farmers' perceptions and practices for managing tomato leaf curl virus disease in southern India. International Journal of Pest Management, 48: 333-338.

Papayiannis, L. C., N. I. Katis, A. M. Idris and J. K. Brown. 2011. Identification of Weed Hosts of Tomato yellow leaf curl virus in Cyprus. Plant Disease, 95: 120-125.

Polston, J. E. and P. K. Anderson. 1997. The Emergence Of Whitefly-Transmitted Geminiviruses in Tomato in the Western Hemisphere. Plant Disease, 81: 1358-1369.

Polston, J. E. and M. Lapidot. 2007. Management of Tomato yellow leaf curl virus: US and Israel Perspectives. Tomato Yellow Leaf Curl Virus Disease. Springer Netherlands, pp. 251-262.

Silber, A., I. Levkovitch and E. R. Graber. 2010. pHDependent Mineral Release and Surface Properties of Cornstraw Biochar: Agronomic Implications. Environmental Science \& Technology, 44: 9318-9323.

Slaughter, A., X. Daniel, V. Flors, E. Luna, B. Hohn and B. Mauch-Mani. 2011. Descendants of Primed Arabidopsis Plants Exhibit Resistance to Biotic Stress. PLANT PHYSIOLOGY, 158: 835-843.

Tufa, R. J. N. 2016. Effects of seed priming on seedling performance of common bean (Phaseolus vulgaris L.) under greenhouse condition Int. J. Res. Granth., 4: 222-228.

Valverde, R. A., P. Lotrakul, A. D. Landry and J. E. Boudreaux. 2001. First Report of Tomato yellow leaf curl virus in Louisiana. Plant Disease, 85: 230-230.

Whitman, T., C. Pepe-Ranney, A. Enders, C. Koechli, A. Campbell, D. H. Buckley and J. Lehmann. 2016. Dynamics of microbial community composition and soil organic carbon mineralization in soil following addition of pyrogenic and fresh organic matter. The ISME Journal, 10: 2918-2930.

Yeboah, E., G. Asamoah, B. Kofi and A. A. Abunyewa. 2016. Effect of Biochar Type and Rate of Application on Maize Yield Indices and Water Use Efficiency on an Ultisol in Ghana. Energy 
Procedia, 93: 14-18.

Zhang, R., F. Murat, C. Pont, T. Langin and J. Salse. 2014.
Paleo-evolutionary plasticity of plant disease resistance genes. BMC Genomics, 15: 187. 